\title{
Mothers who were sexually abused during childhood are more likely to have a child victim of sexual violence
}

\author{
Mães que sofreram abuso sexual na infância têm maior chance de ter \\ um filho vítima de violência sexual
}

Luis Eduardo Wearick-Silva, ${ }^{1}$ Saulo G. Tractenberg, ${ }^{2}$ Mateus L. Levandowski, ${ }^{2}$ Thiago W. Viola, ${ }^{1}$ Joelza M. A. Pires, ${ }^{3}$ Rodrigo Grassi-Oliveira ${ }^{1,2}$

\begin{abstract}
Introduction: Recurrent exposure to childhood sexual abuse (CSA) seems to be higher among victims of sexual abuse. In this sense, experiences related to sexual violence can perpetuate within the family context itself in various ways. Here, we investigate the association between being exposed to CSA and having a child victim of sexual abuse.

Method: We used a sample with 123 mothers, who were divided into 2 groups: one consisting of 41 mothers of sexually abused children and another consisting of 82 mothers of non-sexually abused children. History of exposure to CSA was evaluated by means of the Childhood Trauma Questionnaire - Short Form (CTQ) and we used a logistic regression model to estimate the prediction values regarding having or not a child exposed to sexual violence. Results: Mothers of sexually abused children had significantly higher scores on CTQ, especially on the sexual abuse subscale (SA). According to our logistic regression model, higher scores on the CTQ significantly predicted the status of being a mother of children exposed to sexual violence in our sample (Wald = 7.074; $p=0.008 ; \operatorname{Exp}(B)=1.681$ ). Years of formal education reduced the likelihood of having a child victim of sexual violence $($ Wald $=18.994 ; p=0.001 ; \operatorname{Exp}(B)=0.497)$.

Conclusion: Our findings highlight the importance of a possible intergenerational effect of sexual abuse. Family intervention and prevention against childhood maltreatment should take this issue in account.
\end{abstract}

Keywords: Child sexual abuse, sexual abuse, family violence, intergenerational relations.

\section{Resumo}

Introdução: A recorrência da exposição ao abuso sexual na infância (ASI) parece ser maior entre vítimas de abuso sexual. Nesse sentido, experiências relacionadas à violência sexual podem perpetuar-se dentro do próprio contexto familiar por diversas maneiras. Aqui, investigamos a associação entre ser exposto a ASI e ter um filho vítima de abuso sexual.

Método: Usamos uma amostra com 123 mães, que foram divididas em 2 grupos: um composto por 41 mães de filhos abusados sexualmente e outro composto por 82 mães de filhos não abusados. O histórico da exposição à ASI foi avaliado por meio do Childhood Trauma Questionnaire - Short Form (CTQ) e usamos um modelo de regressão logística para estimar os valores preditivos em relação a ter ou não um filho exposto a violência sexual. Resultados: Mães de crianças vítimas de abuso sexual obtiveram maiores escores no CTQ, especialmente na subescala de abuso sexual (SA). Segundo nosso modelo de regressão logística, escores maiores no CTQ foram capazes de predizer significativamente a categoria de ser ou não mãe de uma criança vítima de violência sexual em nossa amostra (Wald $=7,074 ; \mathrm{p}$ $=0,008 ; \operatorname{Exp}(B)=1,681)$. O número de anos de escolaridade reduziu a chance de ter um filho vítima de violência sexual (Wald $=18,994 ; p=0,001 ; \operatorname{Exp}(B)=0,497)$.

Conclusão: Nossos achados ressaltam a importância de um possível efeito intergeracional do abuso sexual. Intervenções familiares e preventivas contra maus-tratos na infância deveriam levar em consideração essa problemática.

Descritores: Abuso sexual infantil, abuso sexual, violência familiar.

\footnotetext{
${ }^{1}$ Graduate Program in Pediatrics and Child Health, Pontifícia Universidade Católica do Rio Grande do Sul (PUCRS), Porto Alegre, RS, Brazil. ${ }^{2}$ Centre of Studies and Research in Traumatic Stress, PUCRS, Porto Alegre, RS, Brazil. ${ }^{3}$ Universidade Federal do Rio Grande do Sul (UFRGS), Porto Alegre, RS, Brazil.

Financial support: none.

Submitted Nov 12 2013, accepted for publication Jan 20 2014. No conflicts of interest declared concerning the publication of this article.

Suggested citation: Wearick-Silva LE, Tractenberg SG, Levandowski, ML, Viola TW, Pires JM, Grassi-Oliveira R. Mothers who were sexually abused during childhood are more likely to have a child victim of sexual violence. Trends Psychiatry Psychother. 2014;36(2):119-122. http://dx.doi.org/10.1590/2237-6089-2013-0054
} 


\section{Introduction}

Childhood sexual abuse (CSA) has been regarded as one of the most serious social and health problems worldwide, ${ }^{1-3}$ with a prevalence estimated at $7.9 \%$ to men and $19.2 \%$ to women. ${ }^{3}$ CSA is defined as acts committed by adults or significantly older individuals where a child is used for sexual gratification or sexual stimulation. ${ }^{4,5}$ The forms of CSA may include engagement in sexual activities with children, such as rape, attempted rape, genital stimulation, or genital exposure. ${ }^{6}$

Several reports have indicated that exposure to sexual abuse during childhood is associated with several neurobiological, behavioral, and neuropsychological consequences. $^{7-11}$ For instance, some authors have suggested a causal relation between exposure to sexual abuse and the development and aggravation of various psychopathological conditions, such as depression, ${ }^{12}$ posttraumatic stress disorder, ${ }^{13}$ substance use disorders, ${ }^{14,15}$ and eating disorders. ${ }^{16}$ Additionally, the deleterious consequences of CSA do not affect only the victim, but, in most cases, all victim's family members, pointing out that the long-term effects of exposure to CSA may be associated with the victim's parents and relatives. Besides, evidences indicate that often most of sex offenders and perpetrators are relatives or friends of abused children (up to $90 \%$ ) and the abuser might have daily contact with the victim. ${ }^{17}$

Considering the role of family members in the incidence of CSA, we suggest that specific parental experiences may also reoccur in children on an intergenerational basis. This conception proposes that the context where children grow and, especially, the way how they learn behavioral patterns in social interaction can increase or decrease the possibility that children expose themselves to dangerous experiences, including situations of interpersonal violence. According to this idea, there is evidence that mothers who have reported CSA provide their children with less support, particularly because they exhibit changes with regard to mother-child attachment patterns. ${ }^{18,19}$ Likewise, studies show that mothers who have experienced CSA are more likely to have a child suffering some kind of abuse or maltreatment in the early years of life. ${ }^{18}$ Thus, these reports indicate that a maternal history of CSA may constitute a risk factor for further occurrence of sexual abuse among children, but this association still requires investigation.

To provide data regarding the main issue of child maltreatment perpetuation, considering that various deleterious consequences are associated with exposure to CSA, this study aimed to investigate the possible intergenerational characteristics of sexual abuse, by investigating the association between history of CSA in mothers of children exposed to sexual violence.

\section{Method}

This study had 123 female participants, all of them mothers of children aged from 10 to 16 years. They were divided into 2 groups: one consisting of 41 mothers of sexually abused children and another consisting of 82 mothers of non-sexually abused children. All mothers of abused children were recruited from a child abuse protection service in Porto Alegre, Rio Grande do Sul, Brazil. The occurrence of sexual abuse among children was confirmed by judicial investigation, which takes place in order to include these children in this protection program. Mothers of non-sexually abused children were recruited by convenience at a psychological research center. All participants were informed about the study and signed a consent term. This study was approved by the Research Ethics Committee of Pontifícia Universidade Católica do Rio Grande do Sul (PUCRS).

Histories of childhood trauma among mothers were evaluated by means of the Childhood Trauma Questionnaire - Short Form (CTQ), ${ }^{20}$ which is extensively used to investigate on a retrospective basis child neglect and abuse. CTQ is a self-reporting questionnaire that assesses childhood trauma at five subscales: physical abuse (PA), emotional abuse (EA), sexual abuse (SA), emotional neglect (EN), and physical neglect (PN). Each subscale consists of five questions rated on a 5-point Likert scale. Different scores are given on each subscale. Data were analyzed using the software SPSS, version 17.0. Mean value, standard deviation, and frequency were calculated, as well as the difference between groups, using $t$ test and chi-square test. To ascertain the predictive power of a maternal history of CSA with regard to having a sexually abused child, a logistic regression model was adopted with the following independent variables: age, years of formal education, and CTQ SA score. All analyses were two-tailed and the significance level was set at $p<0.05$.

\section{Results}

The mothers of sexually abused children had significantly higher score on CTQ, as well as on the subscales of physical abuse, emotional abuse, physical neglect, and emotional neglect, compared to the mothers of non-sexually abused children. Specifically, the mothers of sexually abused children showed a mean of 7.63 on the sexual abuse subscale, regarded as moderate to severe trauma according to the manual of CTQ. On the subscales of emotional abuse and physical abuse, participants 
Table 1 - Sociodemographic variables and participants' scores on CTQ

\begin{tabular}{|c|c|c|c|c|}
\hline \multirow[b]{2}{*}{ Variable } & \multicolumn{2}{|c|}{ Mothers of sexually abused children } & \multirow[b]{2}{*}{ Statistics } & \multirow[b]{2}{*}{$\mathbf{p}$} \\
\hline & $\begin{array}{c}\text { Yes }(n=41) \\
\text { Mean }(\text { SD) }\end{array}$ & $\begin{array}{c}\text { No }(n=82) \\
\text { Mean }(\text { SD) }\end{array}$ & & \\
\hline Age & $31.80(12.13)$ & $36.06(10.26)$ & $t(121)=2.03$ & $0.044 *$ \\
\hline Years of formal education & $8.26(4.51)$ & $13.39(3.20)$ & $\mathrm{t}(121)=7.25$ & $0.000^{+}$ \\
\hline Sexual abuse during childhood & $13(31.70 \%)$ & $3(3.65 \%)$ & $\chi^{2}=19.003$ & $0.000^{+}$ \\
\hline \multicolumn{5}{|l|}{ Scores on CTQ } \\
\hline Total & $57.85(10.29)$ & $53.46(4.26)$ & $t(121)=-3.34$ & $0.001^{+}$ \\
\hline Emotional abuse & $11.58(5.04)$ & $8.32(2.94)$ & $t(121)=-4.51$ & $0.000^{+}$ \\
\hline Sexual abuse & $7.63(4.58)$ & $5.20(0.85)$ & $t(121)=-4.65$ & $0.000^{+}$ \\
\hline Physical abuse & $8.19(3.68)$ & $6.19(1.82)$ & $t(121)=-4.03$ & $0.000^{+}$ \\
\hline Physical neglect & $13.29(3.05)$ & $13.28(1.36)$ & $t(121)=-0.03$ & 0.976 \\
\hline Emotional neglect & $20.45(3.73)$ & $17.14(5.42)$ & $\mathrm{t}(121)=3.95$ & $0.000^{+}$ \\
\hline
\end{tabular}

Values showed as mean (standard deviation) or number of participants (\%).

CTQ $=$ Childhood Trauma Questionnaire

$* \mathrm{p}<0.05 ;+\mathrm{p}<0.001 ; \chi 2=$ chi-square test.

showed a mean of 11.58 and 8.19 , respectively, which are classified as mild to moderate trauma. The mean values of the mothers of non-sexually abused children were classified as none to mild severity. In addition, there were differences between groups with regard to age and years of formal education. This data is shown in Table 1.

According to our logistic regression model, higher scores on the CTQ significantly predicted the status of being mother of sexually abused children in our sample $\left(\chi^{2}=47.955 ; \mathrm{df}=3 ; \mathrm{p}=0.001\right)$. The CTQ SA score significantly increased the odds of having sexually abused children $(\beta=0.520 ;$ SE $=0.195$; Wald $=7.074$; $p=0.008 ; \operatorname{Exp}(\beta)=1.681 ; 95 \%$ CI 1.14-2.46), while years of formal education reduced it $(\beta=-0.699$; SE $=0.160 ;$ Wald $=18.994 ; \mathrm{p}=0.001 ; \operatorname{Exp}(\beta)=0.497$; 95\%CI 0.36-0.68).

\section{Discussion}

This study investigated the association between being exposed to CSA and having a child also victim of sexual abuse. The main finding was that mothers who have been sexually abused during childhood are more likely to have an abused child. It is consistent with the results of previous reports demonstrating this association. ${ }^{21-24}$ Furthermore, we found that mothers of abused children were also more likely to have been exposed to other early adversities (e.g. physical and emotional abuse and/ or emotional neglect) than mothers whose children have not been sexually abused. These findings are consistent with the theoretical framework emphasizing the impact of mothers' developmental history on their children's developmental outcomes.

There are many possible indirect sources that can contribute to perpetuate abuse history within families. ${ }^{24-27}$
In a three-generational study, Leifer et al., ${ }^{28}$ for instance, observed three factors reinforcing sexual abuse perpetuation: 1) presence of maternal psychopathology and/or distress; 2) disruption in maternal care patterns; and 3) negative relationship with family members. Other findings have been suggested, such as the fact that mothers who have been abused during childhood were more likely to be involved with partners who show abusive models of masculinity, increasing children's risk to experience maltreatment. ${ }^{27}$

When abused women become mothers, they tend to show poor maternal functioning and difficulty to attach to their own children. ${ }^{24,27}$ Apparently, maternal attachment constitutes a major determinant of child development outcomes. ${ }^{27,29-31} \mathrm{~A}$ poor attachment quality may have severe consequences for offspring. Insecure and disorganized attachment patterns, for instance, have been associated with greater risk for developing psychopathology both during childhood (e.g. internalizing and externalizing symptomatology) ${ }^{27}$ and adulthood (e.g. depressive and anxiety symptoms, substance use disorders). ${ }^{26,31}$

Regardless of findings, this study has some limitations. First, we did not include other sociodemographic data, such as income, for instance, and previous studies have shown that children are more likely to be victims of sexual abuse in extremely poor areas. ${ }^{32}$ Second, considering the logistic regression model adopted, our study was conducted with a small sample size. Third, many studies suggest that in retrospective surveys on childhood maltreatment assessment, some abilities to recall this kind of information can show to be impaired, due to the impact of exposure to stressful life events. ${ }^{33}$ However, besides the great controversy concerning the reliability and validity of retrospective information, this study used a retrospective self-reporting of childhood maltreatment. 
Fourth, due to ethical issues, we had no access to legal records concerning peculiarities of sexual abuse events, including perpetrator identification. Therefore, we should be cautious to generalize the findings of this study. Further studies need to rely on larger samples, including more variables and relevant interactions in order to predict potential intergenerational effects.

Finally, understanding the complex associations between exposure to CSA and being mother of sexually abused children may be helpful to design and implement preventive interventions and specific strategies to break the cycle of childhood maltreatment, especially regarding intergenerational relations of sexual victimization. ${ }^{34,35}$

\section{References}

1. Molnar BE, Berkman LF, Buka SL. Psychopathology, childhood sexual abuse and other childhood adversities: relative links to subsequent suicidal behaviour in the US. Psychol Med. 2001;31:965-77.

2. Molnar BE, Buka SL, Kessler RC. Child sexual abuse and subsequent psychopathology: results from the National Comorbidity Survey. Am J Public Health. 2001;91:753-60.

3. Pereda N, Guilera G, Forns M, Gómez-Benito J. The prevalence of child sexual abuse in community and student samples: a metaanalysis. Clin Psychol Rev. 2009;29:328-38. Epub 2009 Mar 5.

4. Madu SN, Peltzer K. Risk factors and child sexual abuse among secondary school students in the Northern Province (South Africa). Child Abuse Negl. 2000;24:259-68.

5. Martin J, Anderson J, Romans S, Mullen P, O'Shea M. Asking about child sexual abuse: methodological implications of a two stage survey. Child Abuse Negl. 1993;17:383-92.

6. Vogeltanz ND, Wilsnack SC, Harris TR, Wilsnack RW, Wonderlich SA, Kristjanson AF. Prevalence and risk factors for childhood sexual abuse in women: national survey findings. Child Abuse Negl. 1999;23:579-92.

7. Viola TW, Tractenberg SG, Pezzi JC, Kristensen CH, Grassi-Oliveira R. Childhood physical neglect associated with executive functions impairments in crack cocaine-dependent women. Drug Alcohol Depend. 2013;132:271-6. Epub 2013 Mar 9.

8. Teicher $\mathrm{MH}$, Andersen $\mathrm{SL}$, Polcari A, Anderson CM, Navalta $\mathrm{CP}$, Kim DM. The neurobiological consequences of early stress and childhood maltreatment. Neurosci Biobehav Rev. 2003;27:33-44.

9. Teicher $\mathrm{MH}$, Andersen SL, Polcari A, Anderson CM, Navalta CP. Developmental neurobiology of childhood stress and trauma. Psychiatr Clin North Am. 2002;25:397-426, vii-viii.

10. Hager AD, Runtz MG. Physical and psychological maltreatment in childhood and later health problems in women: an exploratory investigation of the roles of perceived stress and coping strategies. Child Abuse Negl. 2012;36:393-403. Epub 2012 May 19.

11. Young-Wolff KC, Kendler KS, Prescott CA. Interactive effects of childhood maltreatment and recent stressful life events on alcohol consumption in adulthood. J Stud Alcohol Drugs. 2012;73:559-69.

12. Jumper SA. A meta-analysis of the relationship of child sexual abuse to adult psychological adjustment. Child Abuse Negl. 1995; 19:715-28.

13. Paolucci EO, Genuis ML, Violato C. A meta-analysis of the published research on the effects of child sexual abuse. J Psychol. 2001; 135:17-36.

14. Rind B, Tromovitch P, Bauserman R. A meta-analytic examination of assumed properties of child sexual abuse using college samples. Psychol Bull. 1998;124:22-53.

15. Andersen SL, Teicher $\mathrm{MH}$. Desperately driven and no brakes: developmental stress exposure and subsequent risk for substance abuse. Neurosci Biobehav Rev. 2009;33:516-24. Epub 2008 Sep 30.
16. Smolak L, Murnen SK. A meta-analytic examination of the relationship between child sexual abuse and eating disorders. Int J Eat Disord. 2002;31:136-50.

17. Finkelhor D. Current information on the scope and nature of child sexual abuse. Future Child. 1994;4:31-53.

18. Testa $M$, Hoffman JH, Livingston JA. Intergenerational transmission of sexual victimization vulnerability as mediated via parenting. Child Abuse Negl. 2011;35:363-71.

19. Markham CM, Lormand D, Gloppen KM, Peskin MF, Flores B, Low $B$, et al. Connectedness as a predictor of sexual and reproductive health outcomes for youth. J Adolesc Health. 2010;46:S23-41. Epub 2010 Jan 22.

20. Grassi-Oliveira R, Stein LM, Pezzi JC. [Translation and content validation of the Childhood Trauma Questionnaire into Portuguese language]. Rev Saude Publica. 2006;40:249-55. Epub 2006 Mar 29.

21. Oates RK, Tebbutt J, Swanston H, Lynch DL, O'Toole BI. Prior childhood sexual abuse in mothers of sexually abused children. Child Abuse Negl. 1998;22:1113-8.

22. Kelley SJ. Parental stress response to sexual abuse and ritualistic abuse of children in day-care centers. Nurs Res. 1990;39:25-9.

23. Newberger CM, Gremy IM, Waternaux CM, Newberger EH. Mothers of sexually abused children: trauma and repair in longitudinal perspective. Am J Orthopsychiatry. 1993;63:92-102.

24. Leifer $M$, Kilbane $T$, Kallick S. Vulnerability or resilience to intergenerational sexual abuse: the role of maternal factors. Child Maltreat. 2004;9:78-91.

25. Cicchetti D, Rogosch FA, Toth SL. Maternal depressive disorder and contextual risk: contributions to the development of attachment insecurity and behavior problems in toddlerhood. Dev Psychopathol. 1998;10:283-300.

26. Kwako LE, Noll JG, Putnam FW, Trickett PK. Childhood sexual abuse and attachment: An intergenerational perspective. Clin Child Psychol Psychiatry. 2010;15:407-22.

27. DiLillo D, Damashek A. Parenting characteristics of women reporting a history of childhood sexual abuse. Child Maltreat. 2003;8:319-33.

28. Leifer M, Kilbane T, Grossman G. A three-generational study comparing the families of supportive and unsupportive mothers of sexually abused children. Child Maltreat. 2001;6:353-64.

29. Lyons-Ruth K. Attachment relationships among children with aggressive behavior problems: the role of disorganized early attachment patterns. J Consult Clin Psychol. 1996;64:64-73.

30. Burkett LP. Parenting behaviors of women who were sexually abused as children in their families of origin. Fam Process. 1991;30:421-34.

31. Paredes $M$, Leifer $M$, Kilbane T. Maternal variables related to sexually abused children's functioning. Child Abuse Negl. 2001;25:1159-76.

32. Garbarino J, Sherman D. High-risk neighborhoods and high-risk families: the human ecology of child maltreatment. Child Dev. 1980;51:188-98.

33. Kazdin $A E_{\text {, Kraemer }} \mathrm{HC}$ Kessler RC, Kupfer D], Offord DR. Contributions of risk-factor research to developmental psychopathology. Clin Psychol Rev. 1997;17:375-406.

34. Berlin LJ, Appleyard K, Dodge KA. Intergenerational continuity in child maltreatment: mediating mechanisms and implications for prevention. Child Dev. 2011;82:162-76.

35. Kim K, Trickett PK, Putnam FW. Childhood experiences of sexual abuse and later parenting practices among non-offending mothers of sexually abused and comparison girls. Child Abuse Negl. 2010;34:610-22. Epub 2010 Jun 11.

\section{Correspondence:}

Rodrigo Grassi-Oliveira

Av. Ipiranga, 6681, prédio 11, sala 936, Partenon

90619-900 - Porto Alegre, RS - Brazil

Tel./Fax: +55 (51) 3320.3633, ext. 7740

E-mail: rodrigo.grassi@pucrs.br 